\title{
ANALYSIS OF EXISTENTIAL FEMINISM STRUGGLE OF WOMEN ONLINE DRIVERS DURING THE COVID-19 PANDEMIC
}

\author{
Allen Pranata Putra \\ UniversitasWijaya Putra, allenpranata@unp.ac.id \\ Erwan Aristyanto \\ UniversitasWijaya Putra,erwanaristyanto@uwp.ac.id
}

(C2020 by the authors. Submitted for possible open access publication under the terms and conditions
of the Creative Commons Attribution-ShareAlike 4.0 International License (CC-BY-SA)
license (https://creativecommons.org/licenses/by-sa/4.0/)
DOI:bttp://dx.doi.org/10.30983/ humanisme.v5i2
\begin{tabular}{|l|l|l|}
\hline Submission: October 20, 2021 & Revised : November 29, 2021 & Published : December 31, 2021 \\
\hline
\end{tabular}

\begin{abstract}
This article discusses the women's movement to sustain its existentialism in the COVID-19 pandemic by moving and taking high risks to become female online drivers. Based on research conducted by Simone De Beawvir, who analyzed the film "The Second Sex" using existentialist feminism theory, women are often used as objects and men as subjects because of the man's masculinity and biological circumstances that are considered to support inter-subjective in men. The contribution of this research is the use of existentialist feminism as an anti-thesis of male masculinity by applying it to the empirical conditions of women. The study used feminist ethnographic methods that combine ethnographic interviews and participant observations. The focus of this study lies on the class struggle of women to maintain their existentialism despite having to take bigh job risks and the risk of contracting the COVID-19 virus due to high mobility. This research data analysis technique uses data reduction, data display, and data triangulation. The results showed that women worked as online drivers to become subjects for themselves and act as breadwinners and bousewives in the conditions of the COVID-19 pandemic. Women's struggles in the COVID-19 pandemic undermine the social stigma of society that often makes them objects.
\end{abstract}

Keywords: Class Struggle, COVID-19, Existentialist Feminism

\begin{abstract}
Abstrak
Artikel ini membahas tentang gerakan kaum perempuan untuk mempertahankan eksistensialnya di masa pandemi COVID-19 dengan bergerak dan mengambil resiko tinggi untuk menjadi driver online perempuan. Berdasarkan penelitian yang dilakukan oleh Simone De Beauvoir yang menganalisis film "The Second Sex"menggunakan teori feminisme eksistensialis, perempuan seringkali dijadikan sebagai objek dan laki-laki sebagai subjek karena maskunilitas dari seorang laki-laki dan keadaan biologis yang dianggap mendukung adanya inter-sebujektif pada laki-laki. Kontribusi penelitian ini adalah penggunakan feminisme eksistensialis sebagai anti-thesis maskulinitas laki-laki dengan menerapkan pada kondisi empiris perempuan. Penelitian ini menggunakan metode etnografi feminis yaitu menggabungkan ethnographic interview dan participant observations. Fokus penelitian ini terletak pada class struggle kaum perempuan untuk mempertahankan eksistensialnya meskipun harus mengambil resiko pekerjaan yang tinggi dan resiko tertular virus COVID-19 akibat mobilitas yang tinggi. Teknik analisis data penelitian ini menggunakan reduksi data, display data, verifikasi data dan triangulasi data. Hasil menunjukkan bahwa kaum perempuan bekerja sebagai driver online untuk menjadi subjek bagi dirinya sendiri sekaligus berperan sebagai pencari nafkah dan ibu rumah tangga dalam kondisi pandemi COVID-19. Perjuangan perempuan dalam pandemi COVID-19 meruntuhkan stigma sosial masyarakat yang seringkali menjadikan mereka sebagai objek.
\end{abstract}

Kata Kunci: Class Struggle, COVID-19, Feminisme Eksistensialis 


\section{Introduction}

Gender and equality is a major issue and is discussed around the world. The theme of gender and equality is a criticism of male masculinity which often discredits, discriminates, and oppresses women's rights. This research took place when the implementation of Enforcement of Restrictions on Community Activities (PPKM) to handle the COVID-19 pandemic by using the feminism paradigm that emerged as an anti-thesis from the view of male masculinity and trying to fight for the women's class as a form of equality of economic, political, social rights in society. ${ }^{1}$ The gender debate at least raises a paradigm of biological differences that causes a person to be considered impossible to be feminine because of these biological differences. ${ }^{2} \mathrm{~A}$ man is considered impossible to be feminine, even though femininity does not require specific biological facts but rather a point of view. A man can be feminine by using a woman's perspective. Feminism is not related to one's biological state but one's perspective to see a phenomenon. An analysis in the British Broadcasting Corporation (BBC) explains that "A pattern in which women complete housework and are likely to be punished for not doing their

${ }^{1} \mathrm{H}$ P Hidayahningrum, "Perempuan Dan Politik (Studi Terhadap Kinerja Menteri Keuangan Sri Mulyani Dalam Kabinet Kerja Periode 2016-2018)," Repository.Uinjkt.Ac.Id, 2018 http://repository.uinjkt.ac.id/dspace/bitstream/1234 56789/49254/1/Harumbi Prastya Hidayahningrum.Fisip.pdf.

${ }^{2} \mathrm{H}$ M Dimyati Huda and Limas Dodi, Retbinking Peran Perempuan Dan Keadilan Gender: Sebuah Konstruksi Metodologis Berbasis Sejarah Dan Perkembangan Sosial Budaya (CV Cendekia Press, 2020). job optimally. Such policies do not take women's perspectives into account."

Recent research literature shows encouragement to view the correlation between men and women who are determined based on activities in sharing thoughts and feelings. ${ }^{4}$ The concept of gender is not a natural power of God Almighty, but can be exchanged between individuals over time and local culture. Gender is a society's assumptions based on a person's behavior, identity, expression and role. $^{5} \quad$ Furthermore, the greatest responsibility is owned by both men and women as a form of the natural selection process which is not absolute but continues to evolve following the social relations of living things.

Discrimination against women at least makes the followers of feminism move and demand equal rights. ${ }^{6}$ Various streams of feminism encourage a commitment for women to fight for their existence to get rights in political, economic, social justice and equality in obtaining decent work. The dominance of male masculinity, which is sometimes absolute, does not require this feminist perspective, and the two paradigms will always be in conflict. Feminism thinking

\footnotetext{
${ }^{3}$ Sandrine \& Amelia, "Pandemi Covid-19 Menambah Beban Bagi Perempuan Dan 'bisa Menghapus Perjuangan 25 Tahun Dalam Menciptakan Kesetaraan Gender' - BBC News Indonesia," BBC, November 26, 2020, https://www.bbc.com/indonesia/dunia-55072850.

${ }^{4}$ Bahrudin Hasan, "Gender Dan Ketidak Adilan," Jurnal Signal 7, no. 1 (2019), https://doi.org/10.33603/signal.v7i1.1910.

${ }^{5}$ Alfian Rokhmansyah, Pengantar Gender Dan Feminisme: Pemahaman Awal Kritik Sastra Feminisme (Garudhawaca, 2016).

${ }^{6}$ Siti Dana Retnani, "Feminisme Dalam Perkembangan Aliran Pemikiran Dan Hukum Di Indonesia," Jurnal Ilmu Hukum: Alethea 1, no. 1 (2017): 95-109.
} 
is a social construction that often causes gender inequality ${ }^{7}$.

The prolonged COVID-19 pandemic has disrupted all economic sectors in the world. The first case appeared in China, precisely the city of Wuhan, which later the Chinese state authorities made a statement that "Urgent announcement on the treatment of pneumonia of unknown cause" presented in the Wuhan Municipal Health Committee $^{8}$. Instead of responding quickly to the information, the Indonesian government is struggling and confused about taking concrete steps to reduce the spread of the COVID-19 virus. Normatively, it is said "stay at home" to the community, but it is contradictory to the community's daily needs, which are not met by the state and the limitations of economic activity ${ }^{9}$.

Indonesia is the third Southeast Asian country where women get a heavier share of work during the Covid-19 pandemic. $^{10}$ The existential state of women arises due to the high workload of women, causing these great women to move out of pre-existing social stereotypes and is caused by male domination over women. Furthermore, the distribution of the increase in women's work in Southeast Asia will be explained in Figure 1.

${ }^{7}$ Hasan, "Gender Dan Ketidak Adilan."

${ }^{8}$ Dito Aditia Darma Nasution, Erlina Erlina, and Iskandar Muda, "Dampak Pandemi COVID-19 Terhadap Perekonomian Indonesia," Jurnal Benefita 5, no. 2 (2020): 212, https://doi.org/10.22216/jbe.v5i2.5313.

'Wawan Mas'udi and Poppy S Winanti, "Covid 19: Dari Krisis Kesehatan Ke Krisis Tata Kelola" (Fakultas Ilmu Sosial dan Ilmu Politik UGM: UGM Press, 2020).

${ }^{10}$ Ismail Marzuki et al., COVID-19: Seribu Satu Wajab (Yayasan Kita Menulis, 2021).

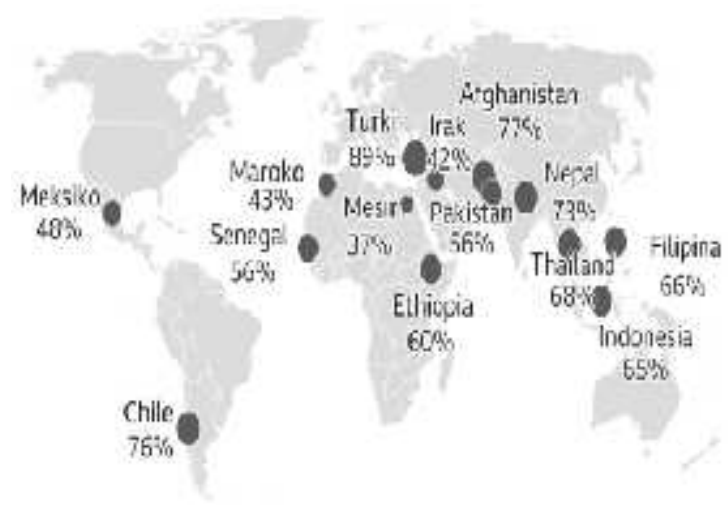

Figure 1. Women's Work Since the COVID19 Pandemic

Source: Sandrine and Amelia Research, $2020^{11}$

Data analysis shows that developing countries such as Indonesia are in the third position in Southeast Asia with 65\% of jobs increasing during the Covid-19 pandemic. Meanwhile, the highest position in Southeast Asia is Thailand with $68 \%$ and the Philippines with $66 \%$. The increasing percentage of women's workload causes high psychological pressure experienced by women as a manifestation of their existential self and the impact of environmental and social pressures. ${ }^{12}$

The impact of the Covid-19 pandemic has logical implications for the economy, which immediately fell and resulted in a decline in purchasing power, causing a prolonged economic recession. Some of the impacts of the COVID-19 pandemic are:

1. Massive layoffs. The data illustrates that more than 1.5 million active workers were laid off and the

11Sandrine \& Amelia, "Pandemi Covid-19 Menambah Beban Bagi Perempuan Dan 'bisa Menghapus Perjuangan 25 Tahun Dalam Menciptakan Kesetaraan Gender' - BBC News Indonesia."

${ }^{12}$ Nila Sastrawati, Laki-Laki Dan Perempuan Identitas Yang Berbeda: Analisis Gender Dan Politik Perspektif Post-Feminisme, 2018, https://id1lib.org/book/5996253/a62273?dsource $=$ r ecommend. 
percentage of $90 \%$ was laid off and $10 \%$ experienced layoffs

2. The value of Purchasing Managers Index for Manufacturing Indonesia fell by $45.3 \%$ in March 2020

3. The import sector fell by $3.7 \%$ in the first quarter of 2020

4. High inflation at $2.96 \%$ (yoy) which came from gold and basic commodities

5. As many as 12,703 flights at 15 airports in Indonesia were canceled and losses reached Rp 207 billion

6. Hotel occupancy up to 6 thousand hotels or around $50 \%$

Sumber: Penelitian Nasution, $2020^{13}$

The extreme occurrence of massive layoffs caused some women to act and move to maintain the existential needs of their families. Research result ${ }^{14}$ shows that $70 \%$ of global media workers are women, $64 \%$ of Indonesian micro, small and medium enterprises (MSMEs) are women and 60\% of the workforce that produces hand sanitizer, hazmat clothes and masks are women. Existentialist feminism provides the perspective that "Individuals who live have responsibilities and have choices, and must be responsible for the consequences of the choices they have made ${ }^{15}$.

The female workforce felt moved to rise up and try to fight the situation they

\footnotetext{
${ }^{13}$ Nasution, Erlina, and Muda, "Dampak Pandemi COVID-19 Terhadap Perekonomian Indonesia."

${ }^{14}$ Fathiyah, "Menlu: Diskriminasi Terhadap Perempuan Saat Pandemi Covid-19 Harus Dicegah," VOA Indonesia, April 20, 2020, https://www.voaindonesia.com/a/menludiskriminasi-terhadap-perempuan-saat-pandemicovid-19-harus-dicegah/5378879.html.

${ }^{15}$ Faidah Yusuf and Muh. Iskandar Susilo, "Existentialist Feminism of Woman's Struggle in Cigarette Girl Novel," IDEAS: Journal on English Language Teaching and Learning, Linguistics and Literature 8, no. 1 (2020): 67-79, https://doi.org/10.24256/ideas.v8i1.1275.
}

were in to act and revolutionize through a form of struggle. The struggle in this regard is not only taking a high risk to become manual labor, but these women must also try to meet the needs of their families, children and husbands who are being deducted from their salaries or laid off due to the COVID19 pandemic. ${ }^{16}$ Some of the anomalies found by the researchers were the work of online drivers which were categorized as unskilled labor which was taken over by women as a form of their struggle. This struggle also supports the husband's responsibility to provide for his family.

The basic empirical problems and theoretical problems described above are about the class struggle of women in the COVID-19 pandemic using the perspective of existentialist feminism. Existentialist feminism is used as the anti-thesis of male masculinity about the concept of subject and object, this is the researcher's effort in developing existentialist feminism theory on women's empirical conditions. This empirical study was conducted in the city of Surabaya, which is the second most populous city after Jakarta, the selection of the city of Surabaya as well as analyzing the increasingly massive transformation of the workforce carried out by women, namely becoming online drivers.

\section{Literature Review}

The first research "The Girl and Simone de Beauvoir's The Second Sex: Feminine Becomings" "17 This study discusses the film The Second Sex (1949). This research is inspired by

${ }^{16}$ Maria Ulfah Anshor, Memutus Rantai Ketidakadilan Global Care Dalam Pengasuban Anak Tenaga Kerja Indonesia Perempuan: Studi Pengasuban Anak TKI Perempuan Pada Pesantren Di Indramayu (Yayasan Pustaka Obor Indonesia, 2017).

${ }^{17}$ Elspeth Mitchell, "The Girl and Simone de Beauvoir's The Second Sex: Feminine Becomings," Australian Feminist Studies 32, no. 93 (2017): 259-75, https://doi.org/10.1080/08164649.2017.1407640. 
Simone de Beauvior's theory of Existential Feminism which contributes to the idea of how to 'become' a woman by not changing gender first, but by equating perspectives to understand the psychological condition of the girl in the film. The similarity of the research that has been done is the use of existentialist feminism theory to analyze the empirical condition of a woman due to the stigma of the subject and object concept. Furthermore, the leak state of the art research is methodologically different from the research conducted, which uses an ethnographic study that is deeply involved in the phenomenon of the female online driver class room.

Second research "Searching for an online space for feminism? The Chinese feminist group Gender Watch Women's Voice and its changing approaches to onlinemisogyny "18 This research has the same theme as the research conducted on inequality against women and the use of the feminism paradigm. This inequality is carried over to women's job acquisition, even though indirectly women always try to maintain their existence in emergency conditions such as the Covid-19 pandemic. The women's movement in China opposes and moves to reject them as the Other to male masculinity. The similarity of the research carried out is the use of class struggle theory to explain the struggle of women who get social stigma that is not good enough. Meanwhile, the location of the state of the art in this research lies in the different research methods and research objects.

${ }^{18} \mathrm{Xiao}$ Han, "Searching for an Online Space for Feminism? The Chinese Feminist Group Gender Watch Women's Voice and Its Changing Approaches to Online Misogyny," Feminist Media Studies 18, no. 4 (2018): 734-49, https://doi.org/10.1080/14680777.2018.1447430.

\section{Existentialist Theory of Feminism}

Existentialist feminism theory is used as a grand theory in this study that seeks to observe an oppressed woman's empirical condition with social stigma about the concept of subject and object. At least every individual has the freedom to make his/her choice and is responsible for the consequences of his/her choice ${ }^{19}$. Early feminist researchers such as Simone de Beauvoir argued that women in the world were only other than men. Often a woman is made an object and a man is a living subject. Beauvoir's view of existentialism opposes this concept and assumes that women can move out of the concept of object into subject for themselves.

a) Subject-Object Relationship (Other)

De Beauvoir's initial analysis in interpreting oppression and violence, which men often carry out, is caused by not properly understanding the concept of subject and object. His opinion is that the relationship between living things will experience intersubjective conflict, humans try to make other humans as objects and do not want themselves to be objects. ${ }^{20}$ Based on the biological fact that women are considered weak in conditions of intense need and support, the history of patriarchy has resulted in women being cornered.

Social construction often simplifies the role of women and the stereotype between men and women is selfinternalization (Otherness). ${ }^{21} \mathrm{~A}$ woman does

\footnotetext{
${ }^{19}$ Yusuf and Susilo, "Existentialist Feminism of Woman's Struggle in Cigarette Girl Novel."

${ }^{20}$ Frederikus Malik, "Peran Teologi Feminis Bagi Pemberdayaan Kaum Perempuan Dalam Sistem Budaya Patriarki Masyarakat Fehalaran" (STFK Ledalero, 2020).

${ }^{21}$ Kurniawan Anas, "Analisis Novel Tanah Tabu Karya Anindita S. Thayf Kajian Feminisme Eksistensialis Simone De Beauvoir" (Universitas Muhammadiyah Mataram, 2019).
} 
not have to be a man's desire, even a woman can become a subject for herself and be involved in social, economic, and political activities. Arguments that prevent women from developing and pursuing their potential to become beings who have essence and nature are not worthy of being considered in any situation.

Several studies explain the interesting fact that women's biological circumstances, physical limitations, and less active roles in organizations are highly dependent on the assessment of each individual as a social being. ${ }^{22}$ Other literature explains that individuals often make women as nature, meaning that women are objects of men because they are acquired as a place for adventure. Women are only considered to produce children - this paradox occurs because women are individuals who can be invited to work together in life, this is only used to provide empirical facts on how marginalization occurs against women. This paradox will persist when stereotypes against women are still running, namely making women only as objects and men as living subjects. ${ }^{23}$

b) Oppression of Women by Men

Oppression and discrimination against gender is not ordinary oppression, history records discrimination against blacks who are oppressed by whites, poor people who are dominated and oppressed by the rich. ${ }^{24}$ Based on the research of Yusuf and Susilo in

${ }^{22}$ Alifiulahtin Utaminingsih, Gender Dan Wanita Karir (Universitas Brawijaya Press, 2017).

${ }^{23} Y a n t i$ Dwi Astuti, "Studi Deskriptif Representasi Stereotipe Perempuan Dalam Iklan Di Televisi Swasta," Profetik: Jurnal Komunikasi 9, no. 2 (2016): 25, https://doi.org/10.14421/pjk.v9i2.1205.

${ }^{24}$ Martha A. Gimanez, "Kapitalisme Dan Penindasan Terhadap Perempuan: Kembali Ke Marx," 2016, 20.
2020 , it is explained that there are at least two reasons for the oppression of women ${ }^{25}$ :

1) The oppression of racial and class is different from the bullying of women's oppression, although historical facts explain the relationship between the two things. Women are subordinate to a man.

2) Women internalize the common view that men are essential and women are not essential.

Beauvoir explains that existentialist feminism rejects the view that women accept themselves as feminine mysteries that are actualized from generation to generation. In the context of the institution of marriage, it will damage the couple's relationship and form slavery. Furthermore, a wife who is also a domestic worker is a feminist whose space is limited.

Meanwhile, women choose to marry for an obligation, marriage is intended to prevent women from men's freedom, but there is no love or individuality without freedom; women must at least give up love for a certain man to ensure that they get life protection from men.

c) Types of Women According to Beauvoir

All women who are involved in a feminine trap, have at least three types who play the role of a "woman", which are as follows: ${ }^{26}$

1) Prostitutes: Women who are willing and willing to become objects of men, those who prostitute themselves not only get money, but as a reward for the services they $\mathrm{do}^{27}$

\footnotetext{
${ }^{25}$ Yusuf and Susilo, "Existentialist Feminism of Woman's Struggle in Cigarette Girl Novel."

${ }^{26}$ Rokhmansyah, Pengantar Gender Dan Feminisme: Pemahaman Awal Kritik Sastra Feminisme.

${ }^{27}$ Sumarlina, "Eksistensi Perempuan Dalam Novel Durga Umayi Karya Y. B Mangunwijaya Berdasarkan Feminisme Eksistensialis Simone de
} 
2) Narcissism: Women who are aware of their appearance so that they can improve their appearance to be able to look beautiful in the eyes of men. In other words, a man will be satisfied to make a woman as his object

3) Mystical: Women who consider themselves more powerful than other women based on societal norms and values are required to be ideal women

This paradox gives the view that a wife, mother, working woman, prostitute, narcissist, and mystical woman are not constructions built by themselves, but constructions built by men through structures and institutions, this is because women are the same as men who also have no essence. Thus, women should be able to become subjects for themselves. Women must refuse to internalize their faith, because accepting Liyan can make women as objects. Examples of cases of women's divisions are the phenomenon of cat calling or whistling and comments to women who are responded to as no problem because they only involve their bodies. This can mean that women separate their mind and body, this is what causes a woman to refuse to be the Liyan.

d) How Women Refuse Liyan

Fajriani's research which also discusses the existential of women explains several strategies that women can use to refuse to be used as Liyan. Patriarchal capitalism, which is abusive and exploitative in nature, is more likely to be employed through a twoshift system: one shift at the office or factory and the other at home. Some feminist observers suspect that no matter how hard a woman's work is, she will lose it altogether if she does not do it. The intellectual activity

Beauvoir," 2018, 1--25, http://eprints.unm.ac.id/id/eprint/13264. of women occurs when someone thinks, defines, and sees, but non-activity occurs when someone becomes the object of thought, definition, and observation. ${ }^{28}$ Beaouvoir encourages women to see world figures who value themselves and explore issues of death, suffering and life.

The form of transformation that women can do is to get a job to fulfill their personal needs. Beaouvoir hopes that the subject-object, self-other conflict between men and women can be resolved when a woman chooses to work. One form of women's liberation is economic power, making women independent individuals. The social environment will restrict women from defining themselves, and women's freedom will be limited by the amount of money they have in the bank.

A woman can resist the internalization of their obligations through identifying themselves with the stereotypes of the dominant group in society. Accepting the other means accepting the status of an object that "rejects the creative self-subject, and has autonomy over itself' and risks going crazy due to engaging in noise. In summary, the class struggle of women can have implications for the resistance to marginalization against them through work, then each woman becomes an intellectual to achieve socialist social transformation. Existentialist feminism finds that there are two things to be analyzed: the marginalization of women as other people and the form of class struggle as a manifestation of existence.

${ }^{28} \mathrm{M}$. Geleuk, W. Mulawarman, and I. Hanum, "Perjuangan Tokoh Perempuan Dalam Novel Tanah Tabu Karya Anindita S. Thayf: Kajian Feminisme Eksistensialis," Ilmu Budaya 1, no. 3 (2017): 240537. 


\section{Methods}

This research is a qualitativedescriptive research with an ethnographic approach to feminism. Feminist ethnographic research is a combination of multiple methods (multi methods research) between ethnographic interviews and participant observation as the main method. ${ }^{29}$ Furthermore, this research has the aim of documenting women's behavior, women's lives and women's empirical activities to be able to explain existential conditions using women's perspectives as a whole, coherently, and conceptualize women's class struggles through expressions that arise from gender relations and social behavior. This observation was conducted to explore women's experiences in existential conditions in society such as contradictory gender positions and class struggles, and the real practice of women in an organization.

Analysis of the data used in this study using triangulation of primary, secondary, and critical analysis of researchers to obtain accurate data. In addition, this study uses data reduction, which is used to reduce several narratives in interviews that are not appropriate to be written down and sources who do not want several narratives to be recorded in the results of ethnographic interviews. Several things must be observed and applied in the ethnographic interview and participant observation method: the level of intimacy between the researcher and the resource person, the attitude of the interviewee's feedback on the interviewer's questions, and being free from ties to the hierarchy. The ethnographic feminism

${ }^{29}$ Rivan Budi Prasetya, "Perempuan Tangguh: Studi Etnografi Feminis Terhadap Empat Pendaki Gunung Perempuan Di Yogyakarta" (Universitas Gadjah Mada, 2018). method was used according to the needs of the researcher's analysis, namely the description, identification and analysis of women's class struggles during the COVID19 pandemic.

\section{Discussion}

\section{Existentialist Feminism Theory}

The interpretation of existentialist feminism theory is based on the existentialist feminism theory described above. The researcher collected empirical data using ethnographic interviews and participant observations, to be used as a critical analysis tool for women's class struggles against oppression, discrimination, and equal rights during the COVID-19 pandemic. Based on the interpretation of Beauvoir's existentialist feminism theory, the following are the ways in which women reject their Liyanas objects:

1) Women as workers. Researcher Simone De Beauvoir analyzed and found that in every oppression carried out by exploitative and discriminatory patriarchal oppressors that injures the conscience of humanity, especially if women have to play various roles in their lives, namely surviving for themselves, housewives, and earning a living for their families. The heavy work done by women remains and always gives women a chance not to be done and lose the chance. ${ }^{30}$ Women who struggle to maintain their existential by working outside the home like men, then these women will take back their direction "women will" significantly raise their ontological

\footnotetext{
30Rohimi, "Perempuan Dalam Proses Pekerjaan Tambang Kapur (Studi Kasus Di Desa Mangkung Kecamatan Praya Barat Kabupaten Lombok Tengah)," Palastren Jurnal Studi Gender 13, no. $1 \quad$ (2020): 179, https://doi.org/10.21043/palastren.v13i1.5804.
} 
status as subjects and no longer as objects, and as individuals who are active to be able to determine the direction of their destiny and his family based on his existential struggle. ${ }^{31}$

Every sweat that drips and flows will be a witness to the class struggle of women which will cause sadness on the other hand which accumulates and evaporates along with the high rate of mobility of work. The data shows that in an ethnographic interview that was conducted with an online driver named Bu Indah, she explained that:

"I live for myself and of course my family, lately we have had to struggle to adjust to the pandemic situation. Moreover, I have been separated from my husband for almost two years since the start of the pandemic. The burden of my responsibilities piled up, apart from being a housewife, I also have to support my child who is in college."

The empirical data explains that women in the city of Surabaya have a very heavy responsibility and burden of life during the pandemic. In this case, Bu Indah consistently maintains her existential refusal to reject the other as well as the object, so that $\mathrm{Bu}$ Indah becomes a subject for herself and her family. Meanwhile, Mrs. Indah also has to accept the potential risks of manual labor to support her daughter who is still in college.

2) Women become intellectuals, group members of an organization can try to build the transformation and class struggle of women. This intellectual activity is an individual activity in

${ }^{31}$ Gde Artawan, Menembus Patriarki: Refleksi Perjuangan Perempuan Bali Dalam Novel IndonesiaRajawali Pers (PT. RajaGrafindo Persada, 2021). defining, seeing, thinking and not being an object of thought. According to Simone De Beauvoir, women should observe researchers such as Katherina Mansield, Emily Bronte, and Virgina Woolf who value themselves as best they can and struggle with issues of death, life and suffering.

"I registered myself as an online driver because at that time my friends and I were looking for work for our daily needs. Having tried various jobs, we chose to become an online driver until the pandemic took place. Even though we know the risks of our work and high mobility cause great harm to our health, but how else can we not survive."

Ethnographic interviews conducted by researchers showed that women are trying to transform by taking high risks to survive for themselves and meet the needs of those around them. Not many choices are provided for these women in the field of work, especially the level of education they have as high school graduates. In this case, the state has not taken concrete steps and paid attention to the welfare of these great women, and researchers criticize the government that the state should be present in every problem of its people and can use a feminist perspective in observing the phenomena occur.

3) Women work to achieve the socialist transformation of society. Like the researcher Paulo Sartre, Simone De Beauvoir also has the same goal of ending the subject-object conflict that often occurs between men and women. Simone De Beauvoir explained that the main point of women's liberation from oppression, 
discrimination, and equality is economic power, namely independent women. ${ }^{32}$ Beauvoir's initial warning to women is that the environment will always place a barrier to entry to define the ontological integrity of women, and a woman's freedom will always be limited to the nominal amount of money they deposit in the bank. The following is an interview conducted by another female online driver, Mrs. Erna:

"My husband was laid off because the sale of his company was not enough to pay the employees' salaries. Finally, my husband returned to his previous side job, which was being an online driver, after a few months it seemed that our family's needs were not sufficient if we only relied on the income from our husbands. Then I tried to help my husband by becoming a female online driver."

Based on the ethnographic interviews and participant observations that have been carried out, the results show that in the social stigma of society, women should not be the backbone in earning a living. Women are against the stigma of meeting the family's financial needs, so a woman chooses to help earn a living for her family by becoming an online driver. Based on Beauvoir's existentialist feminism theory, this condition causes the subject and object conflict to end because women have become ontologically independent and independent for their families. ${ }^{33}$

4) Going beyond their boundaries, women have the opportunity to

\footnotetext{
${ }^{32}$ Rokhmansyah, Pengantar Gender Dan Feminisme: Pemahaman Awal Kritik Sastra Feminisme.

${ }^{33}$ Yogie Pranowo, "Transendensi Simone De Beauvoir," Melintas 32, no. 1 (2016): 73-93.
}

choose and reject their obligations by identifying individuals through the dominant views in society. Normative views in society can be used to see the feasibility of the class struggle being carried out. Accepting Liyan, according to Beauvoir, is being able to accept objects that have a meaning of self-subject that is independent and autonomous from each individual, even though it takes the consequences of severe depression caused by ontological involvement of the individual. Empirical data obtained from interviews with Mrs. Indah who is a single parent, are as follows:

"If you say that online drivers are underestimated, especially if they are carried out by women. But I never paid attention to the stigma, I was more concerned with the needs of myself and my children to live. Moreover, online drivers have high mobility, we are also sometimes considered to carry viruses. Even though I am also very careful, I also don't want to catch the COVID-19 virus, but customers sometimes think differently."

This explanation shows that women, in this case, get a bad stigma in society because high job mobility causes the stigma that they carry the virus from one place to another. Nonetheless, these great women transcend their boundaries and decide to take existentially about their wholeness. It illustrates that women can become selfsubjects and autonomous towards themselves. This interpretation is in line with support for research ${ }^{34}$ which explains a

${ }^{34}$ Widia Sri Ardias and Fazly Haryudha, "Work Family Conflict Pada Pegawai Wanita Yang Sudah Menikah Dan Memiliki Komitmen Organisasi 
significant positive linear relationship between women's organizational commitment and work-family conflict among married employees. This attention also explains that when a woman chooses to work, she naturally becomes a subject for herself..

\section{Interpretation of Class Struggle Theory}

The movement of women in the city of Surabaya to reject objects by carrying out class struggle is a real movement carried out by the proletariat to get out of oppression, discrimination, and equality between men and women. Class struggle theory was initiated by Karl Marx where society will be divided into two classes, namely the proletariat and the bourgeoisie or the oppressed and the oppressor. The classification is based on the exploitation and oppression of the bourgeoisie, where the proletariat does not get wages commensurate with the work they do. The problem is that if we use the feminist paradigm, we will find that women's homework cannot be converted into money, but its value is equally valuable. A woman takes her time to complete housework which is often not appreciated and is considered not to produce utility, namely money. Marx analyzed that this would lead to "class antagonism" which pushed the proletarian class to be free from oppression and out of the concept of objects. The desire to be free from oppression is the main pillar of the revolution in the new social system (class struggle theory).

The researcher's critical analysis observes that the work of online drivers carried out by women will undoubtedly increase the workload that these women must bear. Based on working hours, female online drivers get inadequate wages because apart from being an online driver for 8

Tinggi," Humanisma: Journal of Gender Studies 4, no. 2 (2020): 224-36. hours, for example, from morning to evening, after work, they have to keep working again to become a housewife and complete the work. It is a form of class struggle to once again survive for themselves and meet their families' needs during the COVID-19 pandemic. Female online drivers let go of the discrimination and oppression that originally occurred and come out to hold on to their own existential. Although in this context the risk of manual labor must also be borne by women, another thing that is the focus of the female online class struggle driver is eliminating stereotypes in society. Proper research ${ }^{35}$ explained that the stereotype of female online drivers appears as a sub-culture in society that male masculinity dominates over more feminine women. This implies that driver work in society is closely related to masculinity and creates stereotypes for women. Another alternative that can be used as a reference in women's class struggle is research ${ }^{36}$ which explains that on the one hand, women's class struggle rejects the domination of men over women, but on the other hand, women's class struggle ambitions are directed to seize the dominant patriarchal system, while the Islamic view places women in a frame of proportionally optimistic rational roles.

\section{Government Efforts Against Women's Movement}

The discussion in this sub-chapter seeks to explain how the government's efforts are against women who are

\footnotetext{
35Shinta Rosalina, Nurhadi Nurhadi, and Yuhastina Yuhastina, "Stereotypes Against Female Online Ojek Drivers in Surakarta," Humanisma: Journal of Gender Studies 5, no. 1 (2021): 54-65.

${ }^{36}$ Septi Gumiandari and Ilman Nafi'a, "Women in The Identity Crisis of Feminism; A Critical Analysis on Gender Movement Based on Islamic Psychology Perspective," HUMANISMA: Journal of Gender Studies 3, no. 1 (2019): 1-12.
} 
experiencing discrimination and negative social stigma in society. Does the government in this case show policy support for female online drivers who are trying to maintain their existence?. Of course, we cannot analyze the integrity of the psychological condition of a woman without showing how the government has contributed to women during the COVID19 pandemic. The feminist paradigm allows to analyze from various perspectives, in this case is the government, furthermore the government's policy towards online drivers will certainly affect the psychological condition of the woman who is struggling to maintain her existence.

The Covid-19 pandemic has forced the government to implement mass mobility restrictions, furthermore, trust in institutions is also very important. ${ }^{37}$ Serious existential threats result in each individual not being able to set aside the wages he earns for his family. Various sources of group threats show that when a group faces external threats, they seek to respond by strengthening and tightening ties within their group. ${ }^{38}$ This argument is supported by the empirical data presented above that public confidence increases during a global health disaster, this is due to a shared need to meet the basic needs of society in order to survive.

Some alternative policies that should be carried out by the government to support and protect or at least slightly side with women during the Covid-19 pandemic are

${ }^{37}$ Jay J Van Bavel et al., "Using Social and Behavioural Science to Support COVID-19 Pandemic Response," PsyArXiv Preprints, March 24, 2020 , $1-50$, https://doi.org/10.31234/OSF.IO/Y38M9.

${ }^{38}$ Katharine H Greenaway and Tegan Cruwys, "The Source Model of Group Threat: Responding to Internal and External Threats.," American Psychologist 74, no. 2 (2019): 218. the awarding and redistribution of the work of nurses. ${ }^{39}$ First, government subsidies as a substitute for wages for female workers who do not work while caring for children because schools and child care are closed due to the Covid-19 pandemic. Second, abolish burdensome requirements to intensively obtain unemployment benefits. Third, expanding the form of unemployment benefits with the Bantuan Langsung Tunai (BLT) scheme to accelerate the Jumlah Uang Beredar (JUB) as a form of accelerating economic growth. Keempat, memperluas akses cuti keluarga dan cuti sakit berbayar. Upaya ini harus selalu intense dilakukan oleh pemerintah dalam pemberdayaan perempuan pada saat pandemi Covid-19.

The rational choice of policies given to the community must be contained at least in the "Nudge" book, namely the government must provide incentives, Understand mapping, Default, Give feedback, Expert error, Structure complex choices which can be shortened to "Nudges". ${ }^{40}$ The government must be the architect of the best choice for society so that women can choose better and rational policies. However, we can also understand that in the implementation of public policies, decisions will always be made through political decisions, which in the book "Why Nations Fail" it is explained that a successful country is a country that implements an inclusive economy and inclusive politics. Inclusive state institutions and an inclusive economy make it very possible to achieve the acceleration of handling Covid-19, while

${ }^{39}$ Titan Alon et al., "The Impact of Covid-19 on Gender Equality," Journal of Chemical Information and Modeling 53, no. 9 (2020): 1689-99.

${ }^{40}$ Cass $\mathrm{R}$ Sunstein and Richard $\mathrm{H}$ Thaler, Nudge: Improving Decisions about Health, Wealth, and Happiness (Penguin Books, 2014). 
at the same time taking the biggest role to be able to prosper the people. The welfare of the community is the main task according to the state constitution and lies also in the 1945 Constitution, which has logical implications for the existential phenomenon of women in Indonesia during the Covid-19 pandemic. A good and more rational policy choice will certainly make it easier for the community to achieve the goals and strategies that have been set previously.

\section{Conclusion}

The COVID-19 pandemic has caused great women in the city of Surabaya to move to get equal rights in obtaining work while maintaining their existence as individual and independent beings. One of the great struggles of the female class in Surabaya is being an online driver, a job categorized as manual labor. Women have the potential to do these jobs, but often there is a bad community and cultural stigma about manual labor. On the other hand, these women ignore society's stigma towards work.

The condition of women's daily needs during the pandemic encourages them to move and transform to fight for their existence. Women can achieve socialist transformation to exceed the limits of their abilities. The real implication of the research is that women have the power to fight for their class and strive for equal equality with men. Due to the great independence of women during the COVID-19 pandemic, women are no more extended objects but become subjects for themselves. Thus, independent women will be free from discrimination, oppression and negative stigma about existential women.

\section{References}

\section{Journal}

Alon, Titan, Matthias Doepke, Jane Olmstead-Rumsey, and Michele Tertilt. "The Impact of Covid-19 on Gender Equality." Journal of Chemical Information and Modeling 53, no. 9 (2020): 1689-99.

Ardias, Widia Sri, and Fazly Haryudha. "Work Family Conflict Pada Pegawai Wanita Yang Sudah Menikah Dan Memiliki Komitmen Organisasi Tinggi." Humanisma: Journal of Gender Studies 4, no. 2 (2020): 224-36.

Astuti, Yanti Dwi. "Studi Deskriptif Representasi Stereotipe Perempuan Dalam Iklan Di Televisi Swasta." Profetik: Jurnal Komunikasi 9, no. 2 (2016): https://doi.org/10.14421/pjk.v9i2. 1205.

Bavel, Jay J Van, Katherine Baicker, Paulo Boggio, Valerio Capraro, Aleksandra Cichocka, Molly Crockett, Mina Cikara, et al. "Using Social and Behavioural Science to Support COVID-19 Pandemic Response." PsyArXiv Preprints, March 24, 2020, 1-50. https://doi.org/10.31234/OSF.IO /Y38M9.

Geleuk, M., W. Mulawarman, and I. Hanum. "Perjuangan Tokoh Perempuan Dalam Novel Tanah Tabu Karya Anindita S. Thayf: Kajian Feminisme Eksistensialis." Ilmu Budaya 1, no. 3 (2017): 240537.

Greenaway, Katharine $H$, and Tegan Cruwys. "The Source Model of Group Threat: Responding to Internal and External Threats." American Psychologist 74, no. 2 
(2019): 218.

Gumiandari, Septi, and Ilman Nafi'a. "Women in The Identity Crisis of Feminism; A Critical Analysis on Gender Movement Based on Islamic Psychology Perspective." Humanisma: Journal of Gender Studies 3, no. 1 (2019): 1-12.

Han, Xiao. "Searching for an Online Space for Feminism? The Chinese Feminist Group Gender Watch Women's Voice and Its Changing Approaches to Online Misogyny." Feminist Media Studies 18, no. 4 (2018): 734-49. https://doi.org/10.1080/14680777 .2018.1447430.

Hanoatubun, Silpa. "Dampak Covid-19 Terhadap Prekonomian Indonesia." EduPsyCouns: Journal of Education, Psychology and Counseling 2, no. 1 (2020): 146-53.

Hasan, Bahrudin. "Gender Dan Ketidak Adilan." Jurnal Signal 7, no. 1 (2019).

https://doi.org/10.33603/signal.v7 i1.1910.

Kasdi, Abdurrohman. "Membangun Kemandirian Melalui Perempuan; Potensi Kedermawanan Untuk Pemberdayaan Perempuan Indonesia." Palastren Jurnal Studi Gender 12, no. 1 (2019): 99. https://doi.org/10.21043/palastre n.v12i1.3184.

Mitchell, Elspeth. "The Girl and Simone de Beauvoir's The Second Sex: Feminine Becomings." Australian Feminist Studies 32, no. 93 (2017): 259-

75.https://doi.org/10.1080/08164 649.2017.1407640.

Nasution, Dito Aditia Darma, Erlina Erlina, and Iskandar Muda. "Dampak Pandemi COVID-19 Terhadap Perekonomian Indonesia." Jurnal Benefita 5, no. 2 (2020): 212. https://doi.org/10.22216/jbe.v5i2. 5313

Pranowo, Yogie. "Transendensi Simone De Beauvoir." Melintas 32, no. 1 (2016): 73-93.

Retnani, Siti Dana. "Feminisme Dalam Perkembangan Aliran Pemikiran Dan Hukum Di Indonesia." Jurnal Ilmu Hukum: Alethea 1, no. 1 (2017): 95-109.

Rohimi. "Perempuan Dalam Proses Pekerjaan Tambang Kapur (Studi Kasus Di Desa Mangkung Kecamatan Praya Barat Kabupaten Lombok Tengah)." Palastren Jurnal Studi Gender 13, no. 1 (2020): 179. https://doi.org/10.21043/palastre n.v13i1.5804.

Rosalina, Shinta, Nurhadi Nurhadi, and Yuhastina Yuhastina. "Stereotypes Against Female Online Ojek Drivers in Surakarta." Humanisma: Journal of Gender Studies 5, no. 1 (2021): 54-65.

Yusuf, Faidah, and Muh. Iskandar Susilo. "Existentialist Feminism of Woman's Struggle in Cigarette Girl Novel." Ideas: Journal on English Language Teaching and Learning, Linguistics and Literature 8, no. 1 (2020): 67-79. https://doi.org/10.24256/ideas.v8i 1.1275 .

Books

Ahmadi, A. Metode Penelitian Sastra Prespektif Monodisipliner, 2019.

Anas, Kurniawan. "Analisis Novel Tanah Tabu Karya Anindita S. Thayf Kajian Feminisme Eksistensialis 
Simone De Beauvoir." Universitas Muhammadiyah Mataram, 2019.

Anshor, Maria Ulfah. Memutus Rantai Ketidakadilan Global Care Dalam Pengasuban Anak Tenaga Kerja Indonesia Perempuan: Studi Pengasuban Anak TKI Perempuan Pada Pesantren Di Indramayu. Yayasan Pustaka Obor Indonesia, 2017.

Artawan, Gde. Menembus Patriarki: Refleksi Perjuangan Perempuan Bali Dalam Novel Indonesia-Rajawali Pers. PT. RajaGrafindo Persada, 2021.

Fajriani R, Nur. "Eksisensi Perempuan Dalam Novel Nadira Karya Leila S. Chudori Berdasarkan Feminisme Simone De Beauvoir." Universitas Negeri Makassar, 2019.

Fathiyah. "Menlu: Diskriminasi Terhadap Perempuan Saat Pandemi Covid-19 Harus Dicegah." VOA Indonesia, April 20, 2020. https://www.voaindonesia.com/a/ menlu-diskriminasi-terhadapperempuan-saat-pandemi-covid-19harus-dicegah/5378879.html.

Gimanez, Martha A. "Kapitalisme Dan Penindasan Terhadap Perempuan: Kembali Ke Marx,” 2016, 20.

Hidayahningrum, H P. "Perempuan Dan Politik (Studi Terhadap Kinerja Menteri Keuangan Sri Mulyani Dalam Kabinet Kerja Periode 2016-2018)." repository.uinjkt.ac.id, 2018.

http:/ / repository.uinjkt.ac.id/dspac e/bitstream/123456789/49254/1/ Harumbi Prastya Hidayahningrum.Fisip.pdf.

Huda, H M Dimyati, and Limas Dodi. Retbinking Peran Perempuan Dan Keadilan Gender: Sebuah Konstruksi Metodologis Berbasis Sejarah Dan
Perkembangan Sosial Budaya. CV Cendekia Press, 2020.

Malik, Frederikus. "Peran Teologi Feminis Bagi Pemberdayaan Kaum Perempuan Dalam Sistem Budaya Patriarki Masyarakat Fehalaran." STFK Ledalero, 2020.

Marzuki, Ismail, Erniati Bachtiar, Fitria Zuhriyatun, Agung Mahardika Venansius Purba, Hesti Kurniasih, Deasy Handayani Purba, Dina Chamidah, Jamaludin Jamaludin, Bonaraja Purba, and Ratna Puspita. COVID-19: Seribu Satu Wajah. Yayasan Kita Menulis, 2021.

Mas'udi, Wawan, and Poppy S Winanti. "Covid 19: Dari Krisis Kesehatan Ke Krisis Tata Kelola." Fakultas Ilmu Sosial dan Ilmu Politik UGM: UGM Press, 2020.

Prasetya, Rivan Budi. "Perempuan Tangguh: Studi Etnografi Feminis Terhadap Empat Pendaki Gunung Perempuan Di Yogyakarta." Universitas Gadjah Mada, 2018.

Rokhmansyah, Alfian. Pengantar Gender Dan Feminisme: Pemahaman Awal Kritik Sastra Feminisme. Garudhawaca, 2016.

Sandrine \& Amelia. "Pandemi Covid-19 Menambah Beban Bagi Perempuan Dan 'bisa Menghapus Perjuangan 25 Tahun Dalam Menciptakan Kesetaraan Gender' - BBC News Indonesia." BBC, November 26, 2020.

https://www.bbc.com/indonesia/ dunia-55072850.

Sastrawati, Nila. Laki-Laki Dan Perempuan Identitas Yang Berbeda: Analisis Gender Dan Politik Perspektif Post-Feminisme, 2018.

https://id1lib.org/book/5996253/ 
a62273?dsource $=$ recommend.

Sumarlina. "Eksistensi Perempuan Dalam Novel Durga Umayi Karya Y. B Mangunwijaya Berdasarkan Feminisme Eksistensialis Simone de Beauvoir," 2018, 1--25. http://eprints.unm.ac.id/id/eprint /13264.

Sunstein, Cass R, and Richard $\mathrm{H}$ Thaler. Nudge: Improving Decisions about Health, Wealth, and Happiness. Penguin Books, 2014.

Taufik, F R. "Analisis Gender Terhadap Ilustrasi Teks Dan Ilustrasi Gambar Dalam Buku Pelajaran Bidang Studi Akidah Akhlak MTS Kelas IX Penerbit Kementerian Agama Tahun 2016," 2020. http://digilib.uinsby.ac.id/id/eprin t/44576.

Udasmoro, Wening. Dari Doing Ke Undoing Gender: Teori Dan Praktik Dalam Kajian Feminisme. Universitas Gadjah Mada Press, 2018.

Utaminingsih, Alifiulahtin. Gender Dan Wanita Karir. Universitas Brawijaya Press, 2017. 